\title{
Quality of sweet potato cultivars planted harvested at different times of two seasons
}

\author{
José Ricardo Tavares de Albuquerque ${ }^{1}$, Rayanne Maria Paula Ribeiro ${ }^{1}$, Leonardo Vieira de Sousa ${ }^{2}$, \\ Giordanio Bruno Silva Oliveira ${ }^{1}$, Hamurábi Anizio Lins ${ }^{1}$, Aurélio Paes Barros Júnior ${ }^{1}$, Elizangela Cabral dos \\ Santos ${ }^{1}$, Patrícia Ligia Dantas de Morais ${ }^{1}$ and Adriano do Nascimento Simões ${ }^{3^{*}}$ \\ ${ }^{1}$ Departament of Crop Science, Universidade Federal Rural do Semi-Árido (UFERSA), Av. Francisco Mota, 572, Costa \\ e Silva, CEP 59625-900, Mossoró, RN, Brazil \\ ${ }^{2}$ Centro de Ciências Agrárias (CCA), Universidade Federal da Paraíba (UFPB), Centro de Ciências Agrárias, Campus II, \\ CEP 58397-000, Areia, PB, Rodovia BR 079, Km 12, Brazil \\ ${ }^{3}$ Unidade Acadêmica de Serra Talhada (UAST), Universidade Federal Rural de Pernambuco (UFRPE), Av. Gregório \\ Ferraz Nogueira, S/N, José Tomé de Souza Ramos, CEP 56909-535, Serra Talhada, PE, Brazil
}

*Corresponding author: adrianosimoesuast@gmail.com

\section{Abstract}

This study aimed at adapting harvest time of different potato cultivars in two seasons during the year. Two experiments were conducted: one in the rainy season and another in the dry period. Two production factors were studied in experiments using a splitplot design in a complete randomized block design. The first factor (including 3 sweet potato cultivars: ESAM 1, Paraná and Mãe de Família) was assigned to the plots. The second factor (harvest time: 90, 105, 120, 135 and 150 days after planting) was assigned to the subplots. Soluble solids, total soluble sugars, starch content, pulp firmness, cooking time and vitamin $\mathrm{C}$ were assessed. The harvest after 150 days resulted in increased levels of soluble sugars, starch, and vitamin $\mathrm{C}$ in both growing seasons, compared to other harvests, demonstrating that tuberization does not depend on season. In addition, late harvesting increased the cooking times with all cultivars, especially those grown in the rainy season. In the dry season, cooking time was higher for cv. ESAM 1 . Of the three sweet potato cultivars, cv. Parana presented the highest total amount of soluble sugars and vitamin C, as well as faster cooking time, while cv. ESAM 1 had the highest starch content, pulp firmness and the longest cooking time. The results suggest that Paraná and Mãe de Família are feasible for the fresh market and ESAM 1 for industry, regardless of the season or harvest time. These cultivars offer growers flexibility when deciding on sweet potato crops for different purposes, i.e. fresh market or in dustry. Delaying the harvest of sweet potatoes until 150 days gives greater flexibility to producers in the semi-arid region of Brazil in relation to either fresh or the industrial market.

Keywords: Ipomoea batatas.; quality; soluble sugars; starch and cooking time.

Abbreviations: DAP_Days after planting; ESAM 1_Escola Superior de Agricultura de Mossoró 1; UFERSA_Universidade Federal Rural do Semiárido; UAST_Unidade Acadêmica de Serra Talhada; IPA_Instituto Agronômico de Pernambuco; DNS_Dinitrosalicylic acid; DFI_Dichlorophenolindophenol; FACEPE_Fundação de Amparo à Ciência e Tecnologia do Estado de Pernambuco; CAPES_Coordenação de Aperfeiçoamento de Pessoal de Nível Superior; N_Nitrogen; OM_Organic Matter; K_Potassium; P_Phosphorus; Na_Sodium; Ca_Calcium; Mg_Magnesium; pH_Hydrogen potential; EC_Electrical Conductivity.

\section{Introduction}

Sweet potato (Ipomoea batatas (L.) Lam.) stands out among crops because it is very important from an economic point of view. Moreover, it is widely distributed in tropical, subtropical and temperate regions (Srisuwan et al., 2006). Sweet potatoes have domestic culinary uses or serve as raw material for industrial processes, e.g. producing sweets, flours, flakes and starch. In Brazil, the industrial use of sweet potatoes is still limited, and it is consumed especially after being cooked. Having a tuberous root with high starch content, it has the potential to be cultivated for industrial purposes (Roesler et al., 2008).

In the Northeast region of Brazil, there is a great diversity of sweet potato cultivars, differing in size and shape. In addition, the color of the skin and pulp of roots can be white, purple, rose-colored, yellow or orange, according to local market preferences, where cultivars with purple, pink and white root skin and white and cream pulp are the most sought after by consumers (Embrapa, 2008).

The introduction of new sweet potato cultivars into the market is an option. For instance, the cv. Paraná has orangecolored skin and pulp, and is rich in vitamin A and beta carotene (Rodriguez-Amaya, 2004). Roesler et al. (2008) evaluated four sweet potato cultivars and found that cultivars had higher yield in the second harvest season than in the first, with an average of 9.14 and $4.25 \mathrm{t} \mathrm{ha}^{-1}$, respectively. For starch production, $\mathrm{CNPH} 003$ was the most 
recommended of the four cultivars because of the presence of roots with lower fiber content, higher dry mass content and higher starch content.

Climatic factors such as air temperature, photoperiod and solar radiation, influence the growth, development and productivity of tuberous roots (Medeiros et al., 1990; Villordon et al., 2010). Twelve clones/cultivars of sweet potato were evaluated by Andrade Júnior et al. (2012), harvested 180 days after planting. Sugar content ranged from 2.3 to $3.5 \%$ and starch content from 16.0 to $23.9 \%$. Clone BD-46 was the richest in sugars, followed by clone BD54 (3.3\%), while clone BD-54 had the highest starch content (23.9\%), followed by clone BD-67 (23.1\%).

Neglecting the crop cycle can result in loss in two ways: when the crop is harvested early and when harvest is performed in advance at 100 days. The losses usually occur because the cultivar does not reach its maximum level of dry matter accumulation in the roots (starch content-related character). Late harvests at 200 days, may increase root rot index and fiber content; thus, reducing quality and occupying the field for a longer period than necessary (Ponte, 2008). Therefore, it is important for farmers to define the best harvest time in relation to time of planting, to better the agricultural lands and to produce higher quality products (Ponte, 2008).

Sweet potato harvest is usually carried out between 120 and 180 days after planting (Azevedo et al., 2014). However, conditions of semi-arid regions (i.e. high temperatures, excess light and little water) are usually limiting factors for harvesting the crop (Medeiros et al., 1990; Villordon et al., 2010). Thus, the introduction of well-established cultivars with colored and potentially sweet pulp in the Southeast and South regions of Brazil such as state of Paraná, must be subjected to pre-harvest adjustments.

The cultivars were selected on the basis of laboratory tests, when they showed excellent performance compared with other cultivars in semi-arid regions. Other aspects were used for the selection of cultivars, such as acceptance in the national and regional market based on external appearance and nutritional composition.

Therefore, the objective of this study was to adapt the harvest time of different sweet potato cultivars in two seasons of the year under semi-arid conditions.

\section{Results and Discussion}

\section{Late harvesting accelerated the accumulation of phytochemicals, indicating potential of sweet potatoes for the fresh market}

After accepting the homogeneity of the variances for soluble solubility, total soluble sugars, starch content, pulp firmness and cooking time, and making a joint analysis of the experiments, triple interaction was found for all these characteristics.

The content of soluble solids and total soluble sugars were increased with late harvesting (Fig. $1 A, B, C$ and D). In the case of soluble solids, the increment was occurred regardless of harvest time and cultivar (Fig. $1 \mathrm{~A}$ and $\mathrm{B}$ ). For total soluble sugars, cv. ESAM 1, always presented the lowest average values in the two crop seasons (Fig. $1 \mathrm{~A}$ and $B)$. In addition, the dry period resulted in a higher sugar increment for all the cultivars (Fig. 1B and D). These results are probably due to high availability of solar radiation for vegetables in the semi-arid region, which increases photoassimilates and apparently drainage efficiency, especially in the dry season.

All cultivars demonstrated an increase in soluble solids and sugars with late harvest time (Fig. 1). This increase was more noticeable in the Mãe de Família and Paraná (Fig. 1). In the dry period, sugar content in these two cultivars reached maximum levels at 120 days, unlike the rainy season, when the same levels reached at 150 days or later (Fig. 1). These findings indicate that the dry season is a period, during which roots can be harvested earlier. Adu-Kwarteng et al. (2014) investigated sweet potato cultivars harvested at 3, 4 and 5 months and found that there was an increase in the content of soluble sugars for all the cultivars with delayed harvest time. The authors also reported values that were higher than those in the present study, ranging from 4.31 to $10.34 \%$ sugar levels. Five months after planting, cultivar Otoo was the richest in sugars $(10.34 \%)$, followed by $\mathrm{cv}$. Faara (8.82\%).

With regard to vitamin C content, homogeneity of variances was not accepted; hence, an isolated analysis of the experiments was performed. In two growing seasons, Paraná was the only cultivar, in which the late harvest time led to an exponential increase (Fig. $2 \mathrm{~A}$ and $\mathrm{B}$ ). Thus, it was found that the late harvest time was the main contributing factor to increase vitamin C content, mainly in Cv. Paraná. The $\mathrm{cv}$. Paraná may have benefited more compared to the other cultivars because of an increase in temperature and high solar incidence for vegetables in the semi-arid region. Harris (1975) reported that the greater the light intensity during growth, the higher the vitamin $C$ content of plant tissues.

According to Zorzella et al. (2003), higher concentrations of vitamin $C$ depend mainly on the type of cultivar. The mean values of vitamin C in cv. Paraná are in line with those reported by Pineli et al. (2005). These authors reported vitamin $C$ content of sweet potatoes between 10 and 30 $\mathrm{mg} .100 \mathrm{~g}^{-1}$ of fresh weight.

The present study highlighted the importance of planting and timing of harvest for sweet potato varieties. In addition, it was found that cultivar Paraná, the only cultivar that is not cultivated in the semi-arid region, has a strong potential for culinary use.

\section{The cultivars presented different potentials for fresh or industry market, regardless of season and harvest time}

In the rainy season, the starch content was increased more rapidly at 120 DAP (Days After Planting), compared to dry season (Fig. 3A). While in the dry period, this increase was occurred between 135 and 150 DAP (Fig. 3B). The dry period also favored greater accumulation of starch compared to the rainy season (Fig. $3 \mathrm{~A}$ and $\mathrm{B}$ ). In addition, CV. ESAM 1, consistently had higher starch content, regardless of the time of year (Fig. 3A and B). Starch is considered to be one of the main components of sweet potato root, comprising 60 to $80 \%$ of the dry weight, followed by the simpler sugars, sucrose, glucose, fructose and maltose (Braun et al., 2010). Regardless of time of harvest and length of growing season, ESAM 1 had the highest starch content, reaching $20.80 \%$ at 120 DAP and $18.42 \%$ at 150 DAP in the first and second 
Table 1. Soil chemical analyses in each growing season, in samples collected at a depth of $0.20 \mathrm{~m}$.

\begin{tabular}{cccccccccc}
\hline $\begin{array}{l}\text { Growing } \\
\text { seasons }\end{array}$ & $\begin{array}{c}\mathrm{N} \\
\left(\mathrm{g} \mathrm{kg}^{-1}\right)\end{array}$ & $\begin{array}{c}\mathrm{OM} \\
\left(\mathrm{g} \mathrm{kg}^{-1}\right)\end{array}$ & $\begin{array}{c}\mathrm{K} \\
-\end{array}$ & $\begin{array}{c}\mathrm{P} \\
\mathrm{mg} \mathrm{dm}{ }^{3}\end{array}$ & $\begin{array}{c}\mathrm{Na} \\
\mathrm{Ca}\end{array}$ & $\begin{array}{c}\mathrm{Mg} \\
\mathrm{cmol}_{\mathrm{c}} \mathrm{dm}^{3}\end{array}$ & $\mathrm{pH}$ & $\begin{array}{c}\mathrm{EC} \\
\mathrm{dS} \mathrm{m} \mathrm{m}^{-1}\end{array}$ \\
\hline Rainy & 0.28 & 11.5 & 172.6 & 135.56 & 11.94 & 2.89 & 1.30 & 8.25 & 8.25 \\
\hline Dry & 1.54 & 29.2 & 62.90 & 211.5 & 5.51 & 6.00 & 1.85 & 7.67 & 7.67 \\
\hline
\end{tabular}
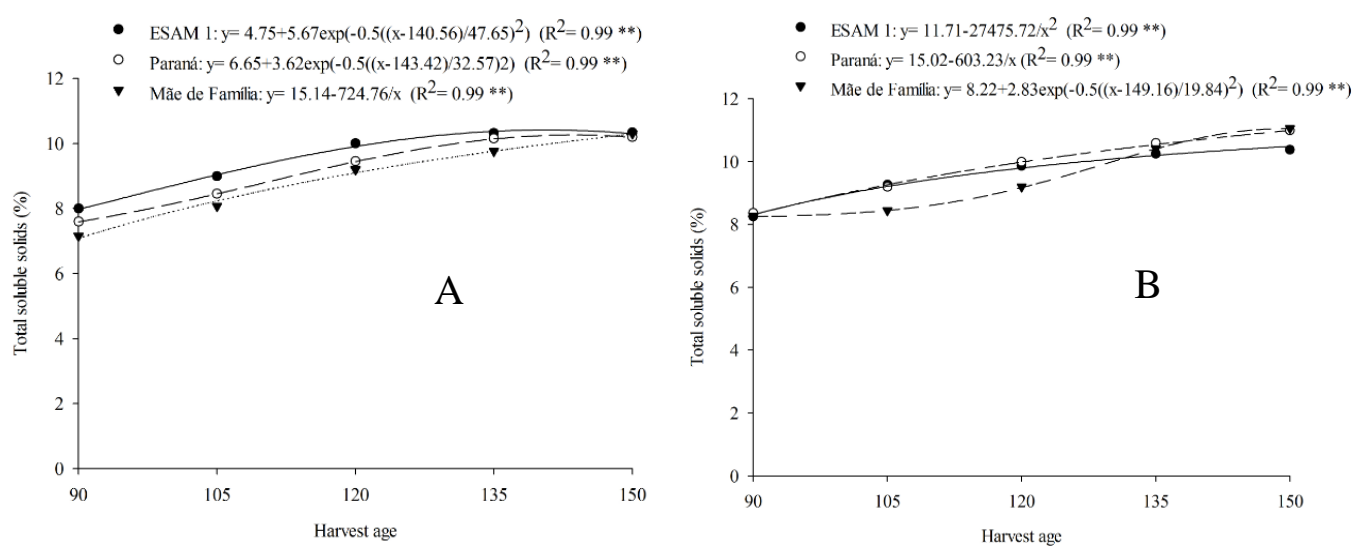

- $\quad$ ESAM 1: $y=4.37-195.40 / \mathrm{x}\left(\mathrm{R}^{2}=0.80 * *\right)$

- Paraná: $y=2.96+1.35 /\left(1+((x-144.58) / 17.13)^{2}\right)\left(R^{2}=0.97 * *\right)$

V Mãe de Familia: $y=4.98-189.93 / \mathrm{x}\left(\mathrm{R}^{2}=0.86 * *\right)$

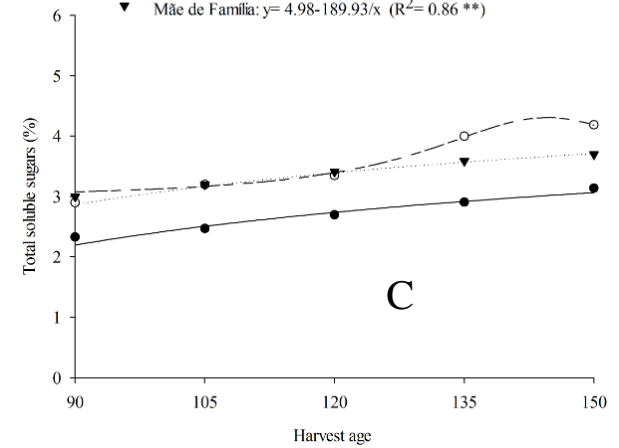

- $\operatorname{ESAM} 1: \mathrm{y}=4.40-89.96 / \mathrm{x}\left(\mathrm{R}^{2}=0.94 * *\right)$

Paraná: $y=4.58+0.66 \exp \left(-0.5((\mathrm{x}-129.34) 15.25)^{2}\right)\left(\mathrm{R}^{2}=0.92 * *\right)$

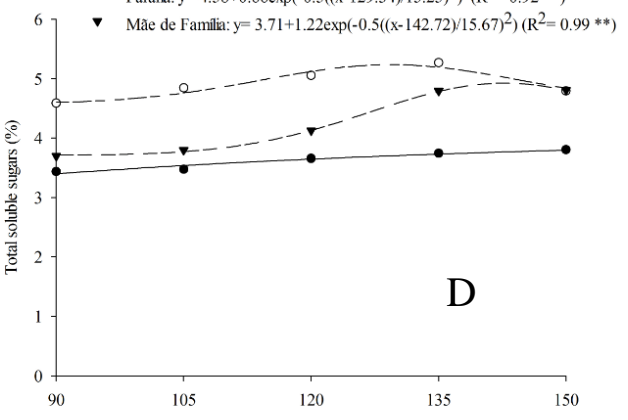

Fig 1. Total soluble solids and total soluble sugar content of sweet potato cultivars harvested at different times and in two seasons (rainy season $A$ and $C$; dry season $B$ and $D$ ).
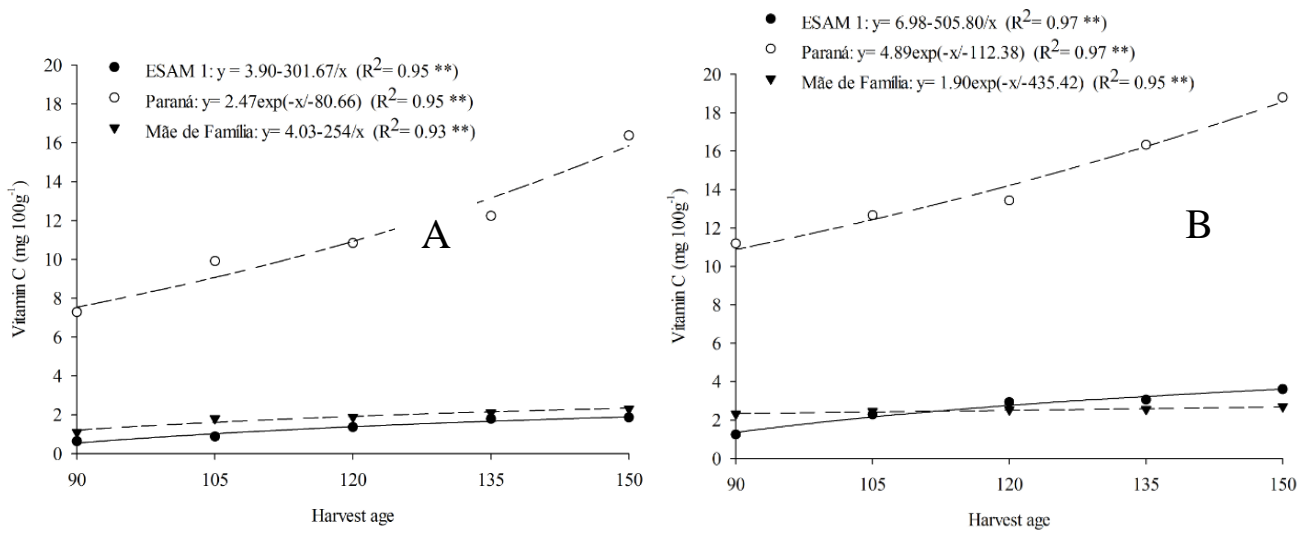

Fig 2. Vitamin C content of sweet potato cultivars harvested at different times and in two seasons (rainy season A; dry season B). 

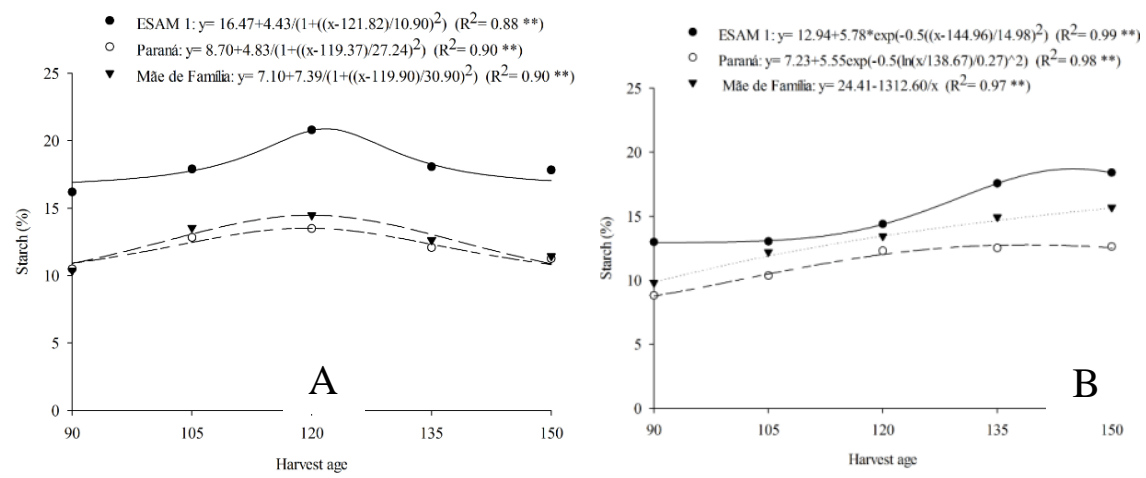

Fig 3. Starch content of sweet potato cultivars harvested at different times and in two seasons (rainy season A; dry season B).
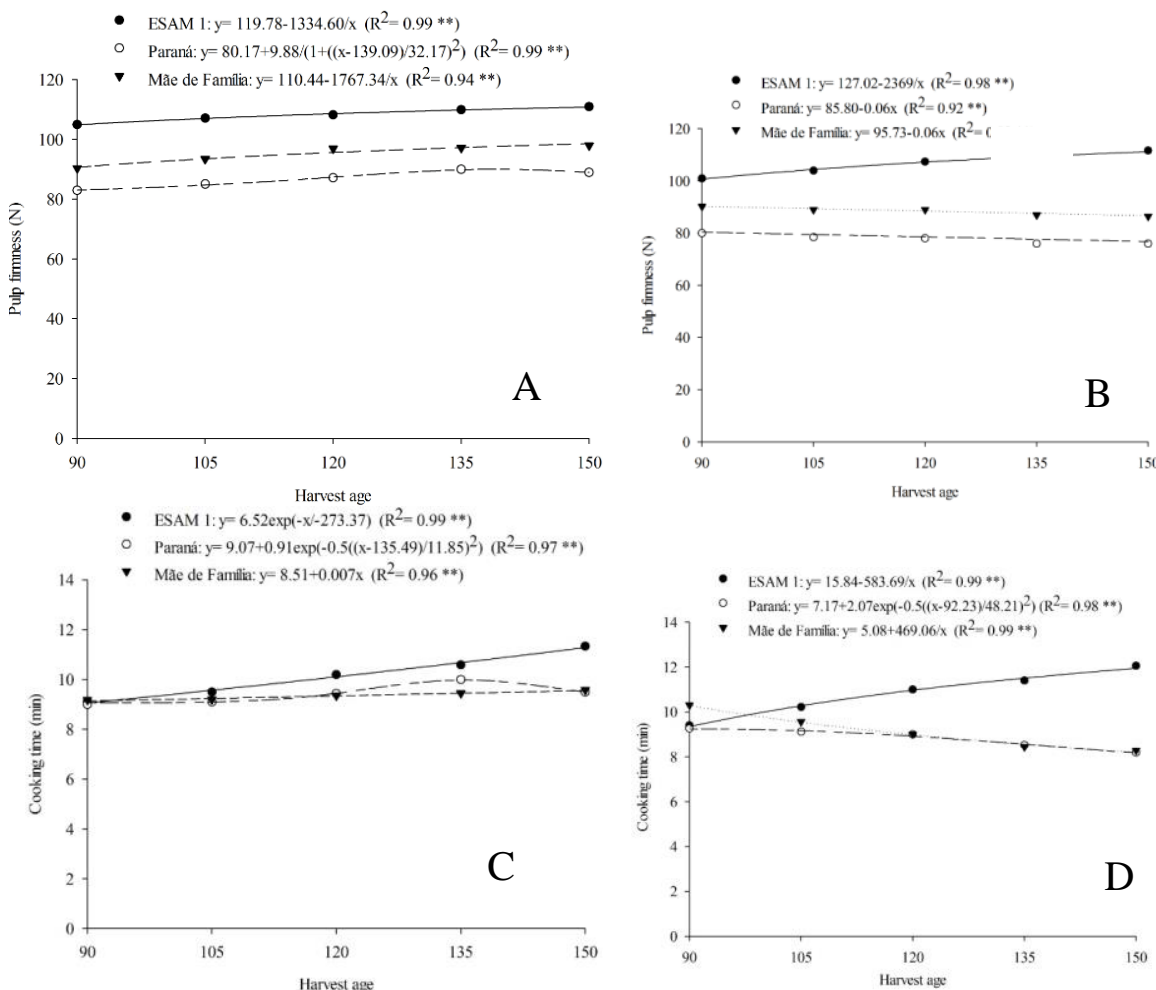

Fig 4. Firmness of pulp and cooking time of sweet potato cultivars harvested at different times and in two seasons (rainy season A and $C$; dry season $B$ and D).

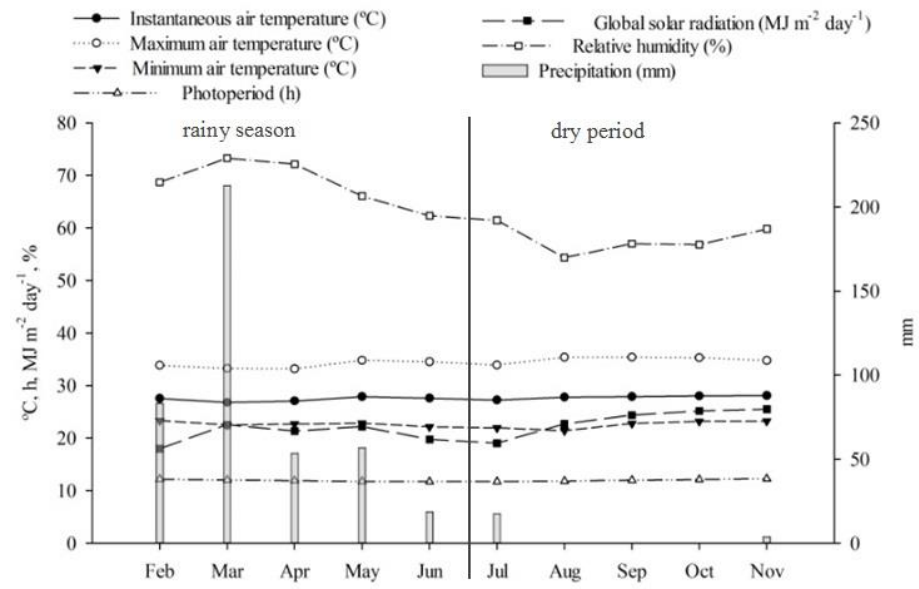

Fig 5. Average values of the instantaneous, maximum and minimum temperatures (으), photoperiod (h), global solar radiation (MJ $\mathrm{m}^{-2}$ day $^{-1}$ ), relative humidity (\%) and precipitation $(\mathrm{mm})$ in each growing season of sweet potato. Source: UFERSA Meteorological Station. 
growing seasons, respectively (Fig. 3A and B). Starch content in sweet potato cultivars ranged from 16.2 to $23.4 \%$ of dry weight according to Nabubuya et al. (2012). In more recent studies, starch contents of 15.4 to $20.3 \%$ have been reported (Senanayake et al., 2013; Ellong et al., 2014), the levels close to those found in the present study.

The results of the present study demonstrated that cvs. Paraná and Mãe de Família are sugar rich and cv. ESAM 1 for starch (Fig. 1 and 3). That selection based on sweetness is one of the main characteristics for choice of root. Thus, cvs. Mãe de Família and Paraná have greater potential for the fresh market, while ESAM 1 has potential for industrial use as a result of its higher starch content. High starch and low soluble sugar contents decrease the cost of sweet potato processing because of the absence of oxidation reactions (Mckibbin et al., 2006). This favors the use of the cv. ESAM 1 for industrial purposes.

With regard to the firmness of fresh sweet potatoes, very similar mean values were reported, comparing wet and dry crops (Fig. 4). In addition, cultivar ESAM 1 consistently presented greater firmness, regardless of season and harvest time (Fig. 4A and B). The firmness of cv. ESAM 1 may be associated with high starch content, as reported by Evangelista et al. (2011) and Fernandes et al. (2015) for sweet potato tubers. Factors that may affect sweet potato texture include starch content and its distribution within the tuber, cell size, cell wall structure and composition (Taylor et al., 2007).

On the other hand, the cultivar Paraná presented lower pulp firmness, regardless of the growing season or harvest time (Fig. 4A and B). This may be associated with lower starch content, resulting in shorter cooking time during the two growing seasons and with the late harvest time (Fig. $4 \mathrm{C}$ and $D)$. With reduced accumulation of starch in the reserve tissues, changes may occur in important characteristics such as texture and firmness of the tuberous root pulp (Chaves et al., 2002). Greater pulp firmness may also be associated with an increase in lignin content, resulting in longer cooking times.

Pereira et al. (1985) categorized cassava and sweet potatoes according to cooking time as follows: optimal cooking (0 to 10 minutes); good cooking (11 to 20 minutes); regular cooking (21 to 30 minutes) and bad cooking (over 30 minutes). The cv. Paraná was the one that had the best cooking time. Cooking time of sweet potato roots is one of the key parameters used in selection for fresh consumption. In this case, cultivars Paraná and Mãe de Família were faster cooking (Fig. 4C and D). Furthermore, in the dry period, results indicated that the older the roots, the shorter the cooking time (Fig. 4C and D). On the other hand, cv. ESAM 1 was associated with the longest cooking time, regardless of season and harvest time, which suggests it should be used in industry.

\section{Materials and Methods}

\section{Characterization of the experimental area and preparation of the experiment}

Two experiments were carried out in two growing seasons in 2015: rainy season (February to June) and dry season (July to November). The study was conducted in the experimental vegetable garden of the Universidade Federal Rural do Semi-
Árido (UFERSA), Mossoró, in the state of Rio Grande do Norte, located geographically at $5^{\circ} 11^{\prime} \mathrm{S} 37^{\circ} 20^{\prime} \mathrm{W}$ and $18 \mathrm{~m}$ altitude. The climate of the region is classified according to Köeppen as BSwh, which is dry and very hot, with two clearly defined climatic seasons, a rainy season (February to May) and a dry season (June to January) (Carmo Filho, Oliveira, 1989). Fig. 5 and Table 1 show the average meteorological data and results of soil chemical analyses for the experimental period.

Plowing and harrowing took place before collection of soil samples for analysis. Ridges of soil were formed at a height of $30 \mathrm{~cm}$ with the aid of a hoe. The soil in the experimental area was classified as Abrupt Eutrophic Red-Yellow Acrisol with sandy texture (Embrapa, 1999).

Two months before the beginning of each experiment, branches of the cvs. ESAM 1, Paraná and Mãe de Família were planted for multiplication purposes.

Planting was carried out on 02/10/2015 and 06/29/2015 during the rainy and dry periods, respectively, with spacing of $1.0 \mathrm{~m}$ between rows and $0.30 \mathrm{~m}$ between plants. Leaf apical branches with eight to ten nodes were harvested on the day before planting and kept in the shade. Two branches were placed in each hole, with three to four nodes buried in the soil, resulting in a total population of 80 plants per experimental plot. The plots were composed of four rows of $3 \mathrm{~m}$ length, with a total area of $12 \mathrm{~m}^{2}$ and representing 4.8 $\mathrm{m}^{2}$ total area.

Fertilization was carried out according to the manual of the IPA (2008). Irrigation was carried out by means of drip tapes, with daily irrigation divided into two applications (morning and afternoon), according to the water requirement of the crop. In the first growing season (rainy season), irrigation was only carried out when required. Manual weeding was conducted as necessary.

\section{Assessment of quality traits}

After harvest, the sweet potatoes were taken to the postharvest laboratory, where several characteristics were assessed. Soluble solids were determined in a digital refractometer with automatic temperature compensation. Total soluble sugars were determined using the Antrona method, according to Yemm and Willis (1954), with spectrophotometer analysis at $620 \mathrm{~nm}$. Starch content was determined by the acid hydrolysis method under reflux and quantified using the DNS reagent, according to (Miller, 1959), with spectrophotometer analysis at $540 \mathrm{~nm}$. The firmness was determined, in which two root readings were carried out on opposite sides of the tuber.

Cooking time was determined using a Mattson cooker, with adaptations to the method proposed by Feniman (2004). Each treatment was replicate for each sample comprising 12 standardized cubes of sweet potato. For each sample, twelve rods (each weighing $131 \mathrm{~g}$ ) were used during the test, with the rod tip positioned at the center of the cube. To start the cooking test, the appliance contained boiling distilled water. The water level inside the container was always kept above the sweet potato cubes throughout the cooking test. Cooking time was determined when $9(80 \%$ plus one rod) of the 12 rods penetrated the cubes and touched the upper part of the modified Mattson cooker. Vitamin C content was determined according to the Adolfo Lutz-IAL Institute (2008), in which a $5 \mathrm{~mL}$ aliquot of juice was 
used. A $45 \mathrm{~mL}$ of $0.5 \%$ oxalic acid was added, followed by titration with $0.02 \%$ 2,6-dichlorophenolindophenol (DCPIP) to the turning point, with a pink color that persists for at least 30 seconds.

\section{Experimental design and statistical analysis}

Two production factors were studied in the experiments, using a split-plot design in a complete randomized block design. The first factor (sweet potato cultivar: ESAM 1, Paraná and Mãe de Família) was assigned to the main plots, while the second factor (harvest time: 90, 105, 120, 135 and 150 days after planting) was assigned to the subplots. Analyses of variance were performed on the evaluated characteristics using SISVAR 3.01 software (Ferreira, 2003). The Bartlett's test for homogeneity of variance was performed on the data (Bustos, 1990; Hoaglin et al., 1992) to verify if the joint analysis of these experiments could be performed, while considering the growing seasons. With regard to the quantitative factors, the procedure for adjustment of the response curves was performed using Table Curve 2D software (Systat software, 2002), with graphs designed using Sigma Plot 12.0 (Systat software, 2011). Tukey's test $(p<0.05)$ was used to compare the means for each growing season.

\section{Conclusion}

Sweet potato cvs. Paraná and Mãe de Família had the highest total soluble sugars and vitamin $C$ contents and the fastest cooking times of the three cultivars, while the ESAM 1 had the highest level of starch, greatest pulp firmness, and longest cooking time. This suggests that cvs. Paraná and Mãe de Familia are ideal for the fresh market, while ESAM 1 is suitable for the industrial market. The dry season of the year accelerated the accumulation of soluble sugars and starch, compared to the rainy season. Delayed harvest increased sugars, starch, and vitamin C contents, compared to earlier harvests. Delaying of sweet potato harvest up to 150 days gives producers of the semi-arid region of Brazil greater flexibility to provide the products to the fresh market or the industrial market.

\section{Acknowledgements}

The Fundação de Amparo à Ciência e Tecnologia do Estado de Pernambuco (FACEPE), and the Coordenação de Aperfeiçoamento de Pessoal de Nível Superior (CAPES).

\section{References}

Adu-kwarteng E, Sakyi-dawson EO, Ayernor GS, Truong V, Shih FF, Daigle K (2014) Variability of sugars in staple-type sweet potato (ipomoea batatas) cultivars: the effects of harvest time and storage. Int J Food Prop. 17:410-420.

Andrade Júnior VC, Viana DJS, Pinto N, Ribeiro KG, Pereira RC, Azevedo AM, Andrade PCR (2012) Características produtivas e qualitativas de ramas e raízes de batata-doce. Hortic Bras. 30:584-589.

Azevedo AM, Andrade Júnior VC, Viana DJS, Elsayed AYAM, Pedrosa CE, Neiva IP, Figueiredo JA (2014) Influence of harvest time and cultivation sites on the productivity and quality of sweet potato. Hortic Bras. 32:21-27.
Braun H, Fontes PCR, Finger FL, Busato C, Cecon PR (2010) Carboidratos e matéria seca de tubérculos de cultivares de batata influenciados por doses de nitrogênio. Cienc Agrotec. 34:285-293.

Bustos O (1990) Estimadores robustos como regras de detecção de dados surpreendentes no modelo de regressão linear. R Bras Estat. 51(196):61-79.

Carmo Filho F, Oliveira OF (1989) Mossoró: um município do semi-árido nordestino "Características climáticas e aspectos florísticos". Mossoró: ESAM, p 62.

Chaves LHG, Pereira HHG (1995) Nutrição e adubação de tubérculos. Campinas: Fundação Cargill, $97 \mathrm{p}$.

Ellong EN, Billard C, Adenet, S (2014) Comparison of physicochemical, organoleptic and nutritional abilities of eight sweet potato (Ipomoea batatas) varieties. Food Nutr Sci. 5:196-211.

EMBRAPA - Empresa Brasileira de Pesquisa Agropecuária. Centro Nacional de Pesquisa de Hortaliças. Cultivo da batata-doce (Ipomoea batatas). Sistemas de Produção, 6. $2008 . \quad$ Disponível em: https://sistemasdeproducao.cnptia.embrapa.br/FontesHT $\mathrm{ML} /$ Batata-doce/Batata-

doce_Ipomoea_batatas/origem.html. Accessed on February 6, 2017.

EMBRAPA - Empresa Brasileira de Pesquisa Agropecuária. Centro Nacional de pesquisa do solo. Sistema brasileiro de classificação de solos. Brasília: Serviço de produção de informação, 412p. 1999.

Evangelista RM, Nardin I, Fernandes AM, Soratto RP (2011) Qualidade nutricional e esverdeamento pós-colheita de tubérculos de cultivares de batata. Pesqui Agropec Bras. 46:953-960.

Feniman CM (2004) Caracterização de raízes de mandioca (Manihot esculenta, Crantz) do cultivar IAC 576-70 quanto à cocção, composição química e propriedades do amido em duas épocas de colheita. 99 f. Dissertação (Mestrado) Escola Superior de Agricultra "Luiz de Queiroz", Unversidade de São Paulo, Piracicaba, SP, 2004.

Fernandes AM, Soratto RP, Moreno LA, Evangelista RM (2015) Qualidade de tubérculos frescos de cultivares de batata em função da nutrição fosfatada. Bragantia. 74:102-109.

Ferreira DF (2003) Programa SISVAR: Sistema de Análise de Variância. Versão 4.6 (Build 6.0). Lavras: DEX/UFLA, 2003.

Harris RS (1975) Effects of agricultural practices on the composition of foods. In: Harris, R.S., Karmas, E. (Eds.), Nutritional Evaluation of Food Processing, 2nd edn. AVI, Westport, CT, pp. 33-57.

Hoaglin DC, Mosteller F, Tukey JW (1992) Análise Exploratória de Dados: técnicas

robustas. Edições Salamandra, Ltda, 446p. Lisboa.

Instituto Adolfo Lutz (2008) Normas Analíticas do Instituto Adolfo Lutz: Métodos Químicos e Físicos para Análise de Alimentos. 4. ed. São Paulo: IAL, 2008. 1020 p.

Instituto Agronômico de Pernambuco (2008) Recomendações de adubação para o estado de Pernambuco: 2a aproximação. 3 ed. revisada. Recife - IPA 2008. 212p.

Medeiros JG, Pereira W, Miranda JECA (1990) Análise de crescimento em duas cultivares de batata-doce (Ipomoea batatas (L.) Lam). Rev Bras Fisiol Veg. 2:23-29. 
Mckibbin RS, Muttucumaru N, Paul MJ, Powers SJ, Burrell MM, Coates S, Purcell PC, Tiessen A, Geigenberger P, Halford NG (2006) Production of high starch, low glucose potatoes through over expression of the metabolic regulator SnRK1. Plant Biotechnol J. 4:409-418.

Miller GL (1959) Use of dinitrosalicylitacid reagent for determination of reducing sugars. Anal Chem. 31:426-428.

Nabubuya A, Namutebi A, Byaruhanga Y, Narvhus J, Wicklund T (2012) Potential use of selected sweet potato (Ipomea batatas Lam) varieties as defined by chemical and flour pasting characteristics. Food Nutr Sci. 3:889-896.

Pereira AS, Lorenzi JO, Valle TL, (1985) Avaliação do tempo de cozimento e padrão de massa cozida em mandiocas de mesa. Rev Bras de Mand. 4:27-32.

Pineli LLO, Moretti CL, Almeida GC, Santos JZ, Onuki ACA, Nascimento ABG (2006) Caracterização química e física de batatas ágata e monalisa minimamente processadas. Ciênc Tecnol Aliment. 26:127-134.

Ponte CMA (2008) Épocas de colheita de variedades de mandioca. Dissertação (Mestrado em Fitotecnia) Universidade Estadual do Sudoeste da Bahia, Vitória da Conquista, 2008.

Rodriguez-Amaya D, Kimura M (2004) Harvest Plus Handbook for Carotenoid Analysis. Harvest Plus Technical Monograph 2. Washington, DC and Cali: International Food Policy Research Institute (IFPRI) and International Center for Tropical Agriculture (CIAT). Copyright Harvest Plus, 2004.

Roesler PVSO, Gomes SD, Moro E, Kummer ACB, Cereda MP (2008) Produção e qualidade de raiz tuberosa de cultivares de batata-doce no oeste do Paraná. Acta Sci Agron. 30:117-122.
Senanayake SK, Ranaweera KKDS, Bamunuarachchi AG (2013) Comparative analysis of nutritional quality of five different cultivars of sweet potatoes (Ipomea batatas (L) Lam) in Sri Lanka. Food Sci Nutr. 1:284-291.

Silva JBC, Lopes CA, Magalhães JS (2002) Cultura da batatadoce. In: CEREDA, M. P. Agricultura: tuberosas amiláceas Latino Americanas. 2. ed. São Paulo: Cargill, 2002. p. 448504.

Srisuwan S, Sihachakr D, Siljak-Yakovlev S (2006) Origin and evolution of sweet potato (Ipomoea batatas Lam.) and its wild relatives through the cytogenetic approaches. Plant Sci. 171:424-433.

Systat software. SigmaPlot for Windows Version 12.0. San Jose: Systat Software Inc., 2011.

Systat software. Table curve 2D and 3D. San Jose: MMIV Systat Software 209 Inc., 2002.

Taylor MA, Mcdougall GJ, Stewart D, (2007) Potato flavor and texture. In: Vreugdenhil D, ed. Potato biology and biotechnology. Oxford, UK: Elsevier, 525-540.

Villordon A, Solis J, Labonde D, Clark C (2010) Development of a prototype bayesian network model representing the relationship between fresh market yield and some agroclimatic variables known to influence storage root initiation in sweet potato. HortScience. 45:1167-1177.

Yemm EW, Willis AJ (1954) The estimation of carbohydrates in plant extracts by anthrone. Biochem J. 57:508-515.

Zorzella CA, Vendruscolo JL, Treptow RO (2003) Qualidade sensorial de "chips" de diferentes genótipos de batatas (Solanum tuberosum L.), cultivos de primavera e outono no Rio Grande do Sul. Rev Bras Agrocienc. 9:57-63. 